\title{
ENGLISH PRONUNCIATION LEARNING IN EFL CONTEXT: STUDENTS' VOICE
}

\author{
Monika \\ English Education Program, STKIP Kusuma Negara, Jakarta \\ monika@stkipkusumanegara.ac.id \\ Neni Winarti \\ English Education Program, STKIP Kusuma Negara, Jakarta \\ neniwinarti@stkipkusumangara.ac.id \\ Audi Yundayani \\ English Education Program, STKIP Kusuma Negara, Jakarta \\ audi_yundayani@stkipkusumanegara.ac.id
}

\begin{abstract}
APA Citation: Monika, Winarti, N, Yundayani, A (2019). English Pronunciation Learning in EFL Context: Students' Voice. Journal of English Language and literature, 4(2), 68-73. DOI 10.37110/jell.v4i02.82
\end{abstract}

\begin{abstract}
English pronunciation mastery is required by English as a foreign language (EFL) students. However, it seems difficult due to several reasons including the differences in producing the English letter comparing with the students' native language. This study aims to identify the EFL students' voice in learning English pronunciation. A descriptive method was applied involving a group of 22 students from the English education program at STKIP Kusuma Negara, Jakarta, Indonesia as a subject of the research. The data of this study were obtained from an observation, a questionnaire, and a semi-structured interview. The results of this study indicate that all respondent realizes the importance of English pronunciation mastery. In addition, they found many challenges in pronunciation learning such as lack of English pronunciation ability, the influence of students' mother tongue in producing the English words, uninterested pronunciation learning process, and low motivation in practicing to pronounce the English words. It is important for the English instructors to develop the strategy in delivering English pronunciation lessons based on students' background including their characteristics as the EFL students.
\end{abstract}

Keywords: EFL students' perception, English pronunciation

\section{INTRODUCTION}

Pronunciation plays a significant role in English learning. It is a crucial part, especially in the area of speaking. People should deliver their speech with proper pronunciation in English in order to be understandable. For Indonesian students, pronouncing the English words is quite hard since they have been using their mother tongue to speak since childhood. Demirezen (2008) believed that a great majority of pronunciation errors are due to inevitable mother-tongue pronunciation habits, which show some resistance to the sounds of the target language. It is a challenge for EFL students to acquire excellent English pronunciation since many different factors affect it. Producing the English sounds relates to delivering the meaning and it seems difficult for foreign students.

In general, pronunciation is a term to describe the production of significant sounds (Dalton \& Seidlhofer, 2001). It is a way in which a language is spoken. In addition, they stated that sound is significant because it is used as part of a particular language code and it is used to achieve meaning in contexts. Their description shows pronunciation as the production and reception of speech sounds and pronunciation with reference to acts of speaking. Kelly (2006) defined the main features of pronunciation into phonemes and 
suprasegmental features. Phonemes are sound units that can be analysed and called segments as well. On the other hand, supra-segmental features are features of speech which are generally applied to groups of segments, or phonemes. Intonation and stress are important features of supra-segmental in the English language. The sounds patterns and suprasegmental competence give a contribution in presenting good communication between speakers. However, those are the crucially essential areas as lack of knowledge and the impact causes communication problems between speakers.

Preliminary research identified that most of the students' seemed unmotivated to involve in pronunciation class actively, while they fully understood the importance of English pronunciation mastery as the important aspect in being able to speak English fluently. Some previous researches in the field of EFL pronunciation had been done by the scholars (Akyol, 2013; Demirezen \& Kot, 2016; Jindapitak, 2015). Yet, the researchers have not found the research which explores students' views related to English pronunciation learning in EFL context. Hence, research is required to gain a better understanding related to English pronunciation learning in EFL context from the students' perceptions. To this end, the purpose of this research was to define the voices of students linked to studying English pronunciation in the context of EFL.

\section{METHODOLOGY}

This paper focuses on describing students' perceptions of English pronunciation learning in EFL context. A descriptive method was applied involving students from the English education program at STKIP Kusuma Negara who were enrolled in pronunciation and phonology course. The research participants were selected through a purposive sampling technique.

In order to find out the students' voice on English pronunciation learning in EFL context, three types of the instrument were used by researchers, namely an observation sheet, a questionnaire, and a semi-structured interview. The research procedure was started from observing the students' attitudes in phonology class, providing a questionnaire to be filled by the students, and conducting a semi-structured interview. The data were analyzed through the concept of Miles \& Huberman (1992). The collected data were reduced, presented, and concluded.

\section{FINDINGS AND DISCUSSION}

Students' voice related to the English pronunciation in EFL context describes that all respondent realizes the importance of English pronunciation mastery. It is in line with the English pronunciation learning goal. Pronunciation course aims to enable students to identify sounds in English, compare English sounds with their native language, pronounce word stress sentence stress, and accurately link sounds within acceptable world English varieties. The observation found that most of the students' lack of motivation for being active in joining the pronunciation course. Furthermore, the students seemed uninterested in practicing the English sounds. They tended to be passive and preferred to not involve in pronunciation course activities.

A questionnaire distributed to explore the research findings. Table 1 explains the questionnaire's result.

Table 1. Students' voice of English pronunciation learning

\begin{tabular}{|l|c|c|c|c|c|}
\hline \multicolumn{1}{|c|}{ Statements } & SA & A & N & D & SD \\
\hline $\begin{array}{l}\text { Learning proper pronunciation is necessary for EFL } \\
\text { students. }\end{array}$ & $72.7 \%$ & $18.2 \%$ & $9.1 \%$ & - & - \\
\hline $\begin{array}{l}\text { Students having lack opportunities to practice English } \\
\text { pronunciation in pronunciation class. }\end{array}$ & $18.2 \%$ & $54.5 \%$ & - & $27.3 \%$ & - \\
\hline $\begin{array}{l}\text { Students having lack opportunities to practice English } \\
\text { pronunciation outside the pronunciation class. }\end{array}$ & $22.7 \%$ & $45.5 \%$ & - & $31.8 \%$ & - \\
\hline $\begin{array}{l}\text { The instructors always use English in presenting a } \\
\text { pronunciation course. }\end{array}$ & - & $54.5 \%$ & $9.1 \%$ & $36.4 \%$ & - \\
\hline
\end{tabular}




\begin{tabular}{|l|c|c|c|c|c|}
\hline $\begin{array}{l}\text { The instructors provide multi teaching strategies in } \\
\text { presenting a pronunciation course. }\end{array}$ & $9.1 \%$ & $27.3 \%$ & $18.2 \%$ & $45.4 \%$ & - \\
\hline $\begin{array}{l}\text { Pronunciation course presented by combining less } \\
\text { pronunciation theory and much pronunciation practice. }\end{array}$ & $9.1 \%$ & $50 \%$ & $27.3 \%$ & $13.6 \%$ & - \\
\hline $\begin{array}{l}\text { The instructors integrated the ICT media in presenting the } \\
\text { pronunciation course. }\end{array}$ & $4.5 \%$ & $22.7 \%$ & $18.2 \%$ & $45.5 \%$ & $9.1 \%$ \\
\hline $\begin{array}{l}\text { The instructors giving constructive feedback in } \\
\text { pronunciation class. }\end{array}$ & $13.6 \%$ & $27.3 \%$ & $9.1 \%$ & $45.5 \%$ & $4.5 \%$ \\
\hline $\begin{array}{l}\text { Students self-confidence in pronouncing the English } \\
\text { words increased after taking pronunciation course. }\end{array}$ & $4.5 \%$ & $36.4 \%$ & $9.1 \%$ & $45.5 \%$ & $4.5 \%$ \\
\hline $\begin{array}{l}\text { Students' ability to pronouncing the English words } \\
\text { improved after taking pronunciation course. }\end{array}$ & $9.1 \%$ & $45.5 \%$ & $13.6 \%$ & $22.7 \%$ & $9.1 \%$ \\
\hline
\end{tabular}

The above table informed that $72.7 \%$ of students believed the necessity of learning proper English pronunciation for the EFL students. In addition, $54.5 \%$ of students thought that they have lack opportunities to practice English pronunciation in pronunciation class, including $45.5 \%$ of students felt that they have lack opportunities to practice English pronunciation outside the pronunciation class. $54.5 \%$ of students identified that the instructors always use English in presenting the pronunciation course and $45.4 \%$ of students informed that the instructors have not provided multi teaching strategies in presenting a pronunciation course. Furthermore, 50\% of students found that pronunciation course presented by combining less pronunciation theory and much pronunciation practice. $45.5 \%$ of students stated that the instructors have not maximized to use the ICT media in presenting the pronunciation course. $45.5 \%$ of students found that the instructors have not given constructive feedback in pronunciation class. In addition, $45.5 \%$ of students felt that their selfconfidence in pronouncing the English words has not increased after taking pronunciation course, and by the end, $45.5 \%$ of students felt that their ability in pronouncing the English words improved after taking pronunciation course.

To strengthen the research findings, the researchers provided several questions to the respondents. The result supported by the findings of the students' questionnaire, to answer the research question about what are the students' voice English pronunciation learning. All of the respondents express different perception appropriate to their experience and feelings during pronunciation learning. In the open question section, the students' views related to the challenges of English pronunciation learning in EFL context are presented in the following extracts. The respondents were asked about their thinking related to their English pronunciation mastery. Three stated:

I found myself having a lack of English pronunciation ability.

\section{I had lack confidence pronouncing the English words. \\ I believed that my friends will laugh at me when I performed the error of pronouncing the English words.}

Regarding another challenge, the influence of students' mother tongue language was also mentioned. Below are the excerpts from the respondents' transcriptions. Two claimed:

My mother tongue influenced my
speech production in English.
Moreover, I felt confused in
pronouncing the English words since
I found some similar letters but
different in pronunciation.

I identified some English sounds which not exist in my mother tongue language.

A statement occurred related to students' motivation. One stated:

I felt uninterested in learning English pronunciation due to my belief that 


\section{English is difficult especially when I found unfamiliar English words to be pronounced.}

As another element which is considered as students' view about the English pronunciation learning in EFL context, we could refer to applied pronunciation teaching strategy. One stated:

\section{I thought that the current pronunciation course still presented in conventional teaching strategy without supported any media and still with a lack of attention and feedback from the instructors. It made the pronunciation learning process seemed monotonous and bored.}

Based on the observation report, the questionnaire, and the interview result, we identify students' voice related to English pronunciation learning in EFL context. All respondent realizes the importance of English pronunciation mastery. It determines their English speaking performance as a foreign language. Demirezen (2010) claims that in the pronunciation of a foreign language, accuracy and intelligibility occupy crucial roles for the quality of a non-native speaking teacher because these two features set up the mutual comprehension and understanding between native speakers and non-native speakers. Demirezen's view is in line with the objective of a pronunciation course. Throughout the pronunciation course, students are expected to be able to pronounce English words correctly, including words stress and appropriately. Furthermore, students should be familiar with the English sound and the differences compared with their native language. In addition, they must be familiar and be able to use the proper intonation in saying the English words.

The research findings describe students' challenges in pronunciation learning such as lack of English pronunciation ability, the influence of students' mother tongue in producing the English words, uninterested pronunciation learning process, and low motivation in practicing to pronounce the English words. Those facts prove that EFL students have many inhibiting factors in learning English pronunciation. Lanteigne (2006) confirms that difficulties in learning English occur because some English sounds do not exist in the mother tongue of the students. Moreover, Thompson and Gaddes (2005) point out that the differences between students' mother tongue and the target language are momentous topics that students should not only be aware of but should make a conscious effort to study and focus on. In line with that opinion, Fledge (2002) stated that the differences in LI sound system and that of the L2 system will mutually influence one another. These findings should be a challenge both for the instructors and students. The proper teaching and learning strategy should be designed based on students' background including their characteristics as the EFL students.

Students' mother tongue language provides significance influence on students' performance in pronouncing the English words. Most of the students realize their shortcomings in English pronunciation and it gives an impact on their self-confidence. Dulay (1982) believed that the first language has been considered as the major cause of a student's problem in the mastering of the new language. Levis (2005) points out two contradictory principles in pronunciation teaching: the nativeness principle, whereby students seek to approximate a standard pronunciation model (e.g., American and British English), and the intelligibility principle, whereby students opt for an ability to make themselves easily understood despite first language (L1) interference in English pronunciation. Moreover, the lack of students' knowledge about the English sound system affects their difficulties in pronouncing English words. The use of technology as a teaching media is fully recommended in presenting the pronunciation course. It can replace the role of native speakers as a model in proper English pronunciation. It is in line with some previous researches. Brown (1992), Claire (1993), Fraser (2000) and Yates (2001) stated that teachers in adult ESL programs face some difficulties meeting the pronunciation learning needs of their students and have indicated that many teachers tend to avoid dealing with pronunciation because they lack confidence, skills, and knowledge (cited in Macdonald, 2002).

The feedback from teachers also plays an important role in the pronunciation class. In the EFL pronunciation class, the teacher should be a feedback giver in addition to being the role 
model in pronouncing the correct English words. In the higher education, feedback must be concerned with developing new ways of knowing (Lea and Street 1998). In addition, the popular view is that feedback should explicitly address future activity, which is feed-forward rather than feedback (Gibbs and Simpson 2004; Torrance 1993). It is essential for the EFL students to get the feedback and it is expected that the feedback can give the positive effect on students' performance especially in English pronunciation. Furthermore, Askew and Lodge (2000) noted that the cognitivist, corrective perspective of feedback is characterized as a ' gift ' from the teacher to the student, where feedback is one-way communication. The socio-constructivist perspective, on the other hand, considers learning as a process that develops through dialog loops where feedback is a method that takes part in a teaching framework (Askew and Lodge 2000). Feedback can connect teachers and students with better communication. Hopefully, if students communicate better with their teacher, they have enhanced their motivation and willingness to improve their pronunciation abilities and correct their errors.

This research finally shows the view of the students on studying English pronunciation in the context of EFL. These findings should be a teacher's recommendation to design the proper

\section{REFERENCES}

Akyol, Tugce. (2013). A study on identifying pronunciation learning strategies of Turkish EFL learners. Procedia - Social and Behavioral Sciences 70, 1456- 1462.

Askew, S., and C. Lodge. 2000. Gifts, pingpong and loops: Linking feedback and learning. In Feedback for learning, ed. S. Askew, chap. 1, 1-17. London: Routledge.

Brown, H.D. (1994). Principles of Language Learning and Teaching $\left(3^{\text {rd }}\right.$ Ed.). Prentice Hall.

Claire, S. (1993). Pronunciation in the NSW Adult Migrant English Service: Current practice future directions. Unpublished master's thesis. University of Technology, Sidney.
English pronunciation course that is in line with the characteristics of the students.

\section{CONCLUSION}

Students' views in the EFL context described their challenges in learning English pronunciation. Most of them realized the importance of English pronunciation mastery. However, many aspects affect the pronunciation learning process from both the inner context of the student such as the interference of their mother tongue language ; lack of motivation and self-confidence ; lack of understanding of English pronunciation and the external background of the students such as the learning process ; monotonous teaching strategy ; lack of teaching media, etc. These circumstances should be the English practitioners ' attention to designing a pronunciation course that is consistent with the characteristics and backgrounds of the students.

\section{ACKNOWLEDGEMENTS}

We gratefully acknowledge our deep appreciation to anyone who supported our research. The remaining errors are our own. Part of this study presented at phonology class as the assignment. We thank the mates for their suggestion. Hopefully, this paper can be submitted for further exploration in a seminar.

Dalton, Christiane \& Seidlhofer, Barbara. (2001). Language Teaching: A Scheme for Teachers Education: Pronunciation. New York: Oxford University Press.

Demirezen, M. (2008). The /æ/ and /है/ phonemes as fossilized pronunciation errors for Turkish English language teachers and students: Undoing the fossilized pronunciation error. Journal of Language and Linguistic Studies, 4(2), 73-82.

Demirezen, M. (2010). The causes of the schwa phoneme as a fossilized pronunciation problem for Turks. Procedia Social and Behavioral Sciences 2, 1567-1571.

Mehmet Demirezen, M. \& Kot, E. (2016). Collegial Reactions to Faulty Pronunciation of Teachers in relation to English Language 
Teaching. Procedia - Social and Behavioral Sciences 232, $471-478$.

Donal, A. (2016). Indonesian students' difficulties in pronouncing English diphthongs. JEE (Journal of English Education), 2(2), 55-62.

Dulay, H., Burt, M., \& Krashen, S. (1982). Language Two. New York: Oxford University Press.

Flege, J. (2002). Interaction between the native and second language phonetic subsystems, Birmingham: University of Alabama.

Fraser, H. (2000). Coordinating improvements in pronunciation teaching for adult learners of English as a second language. Canberra: Department of Education, Training and Youth Affairs.

Gibbs, G., and C. Simpson. 2004. Conditions under which assessment supports students' learning. Learning and Teaching in Higher Education 1, no. 1: 1-31.

Jindapitak, Naratip. (2015). English as a lingua franca: Leaners' views on pronunciation. Electronic Journal of Foreign Language Teaching, 12 (2), pp. 260-275.

Kelly, Gerald. (2006). How to Teach Pronunciation. Malaysia: Pearson Education Limited.

Lanteigne, B. (2006). Common, persistent errors in English by Brazilian Portugese speakers. EFL Web Journal, 4(1). Retrieved August 21, 2016, from
http://www.teflwebj.org/v4n1/Brazilians.pd

Lea, M., and B. Street. 1998. Student writing in higher education: An academic literacies approach. Studies in Higher Education 23, no. 2: $157-72$.

Levis, J. M. (2005). Changing contexts and shifting paradigms in pronunciation teaching. TESOL Quarterly, 39(3), 369377.

Macdonald. S. (2002). Pronunciation- views and practices of reluctant teachers. Prospect 17(3).

Milles \& Huberman. (1992). Analisis data kualitatif. Jakarta: Universitas Indonesia Press.

Price, M., Handley, K., Millar, J., \& O'Donovan, B. (2010). Feedback: all that effort, but what is the effect? Assessment \& Evaluation in Higher Education, 35(3), 277289. doi:10.1080/02602930903541007.

Thompson, T. \& Gaddes, M. (2005). The importance of teaching pronunciation to adult learners. Asian EFL Journal, 1. Retrieved March 25, 2012, from: http://www.asianefl.journal.com/ptafeb 04 mgtt.php.

Yates, L (2001). Teaching pronunciation in the AMEP: Current practice and professional development. AMEP Research Centre, from http: //www.nceltr. mq.edu. au/ conference 2001/index.html. 